\title{
EFFECT OF CULTIVATION MEDIA, IRRIGATION WATER SOURSES AND ORGANIC MANURE LEVELES ON YIELD OF CUCUMBER AND TOMATO UNDER PROTECTED GREENHOUSES AT NORTH DELTA \\ Saied,M.M.; B. A. A. Zamil; G. M. El-Sanat and M. A. Abou El Soud Soil, Water and Environment Research Institute, ARC.
}

\begin{abstract}
This investigation was conducted in plastic greenhouses at Sakha Agricultural Research Station to study the effect of different cultivation media, irrigation water sources and organic manure levels on fresh yield of cucumber and tomato and NPK contents of leaves and $\mathrm{C} / \mathrm{N}$ ratio of rice bales .Split-split plot design with four replicates was used. The obtained results could be summarized as follows:

1. Fresh yield of cucumber grown on rice straw bales was increased significantly compared to clay soil, while tomato fresh yield grown on clay soil was higher than that grown on rice straw bales.

2. Fresh yield of either cucumber or tomato was decreased significantly with irrigation by well water or blended fresh with well water compared to fresh water.

3. Addition 20 ton of organic manure /fed. gave the highest fresh yield of cucumber or tomato, while zero level leads to achieve the lowest yield.

4. $\mathrm{N}$ and $\mathrm{P}$ contents of cucumber leaves were higher under cultivation on clay soil than rice straw bales, while the $\mathrm{K}$ took the opposite trend. Concerning the irrigation water sources, the contents of these elements were higher with fresh water than blended and well water, as well as, addition 20 ton organic manure /fed led to achieve the highest values of NPK content of cucumber and tomato leaves compared to other levels...

5. The $\mathrm{C} / \mathrm{N}$ ratio of rice straw bales is decreased after cucumber and tomato harvesting comparing to that before the experiment. Using fresh water or blended water gave the lowest value of $\mathrm{C} / \mathrm{N}$ ratio with cucumber and tomato .The increase of O.M application level up to 20 ton/fed leads to decrease $\mathrm{C} / \mathrm{N}$ ratio with both growing crops in both seasons.
\end{abstract}

\section{INTRODUCTION}

Straw is a major output of the production of rice, wheat, cotton. faba bean and maize (approximately two-third of the whole plant). Although there are several alternatives for the beneficial use of straw i.e compost, animal feed, roofing material, practical boards, bedding material and media for cultivation, it appears that a large volume of straw is wasted and burnt in the field by the farmers.

This investigation deals with a possible use of rice straw bales as cultivation media for escaping the problems inherent in the natural soils and avoiding serious pollution.

Many researchers showed the low organic matter content of the soils (0.5 $2 \%)$. It is well known that organic matter particularly in clay soil improves the soil structure, increases the water and fertilizer retention capacity at the root zone and increases the microbial activity of the soil , in addition, useful plant 
nutrients are lost when about 5 million ton of rice straw are disposed annually by burning.

El-Aidy (1993) used rice straw as cultivation media for tomato and summarized that the best results were obtained from straw bales half buried in the soil during winter cultivation and from full buried bales during spring cultivation. The increases of the total yield for the best treatment and control were 0.7 and $0.33 \mathrm{~kg} / \mathrm{plant}$ in winter and spring cultivation, respectively.

Abou El- Hassan et al. (1993) concluded that early yield, total yield and nutrient uptake in cucumber fruits slightly differed when plants grown on rice straw in two successive seasons. Concerning plant growth and nutrients uptake in vegetative parts, no significant differences were obtained. All the cultivation media substrates (Rice straw bales and nutrients) under investigation led to an increment in organic matter content at the end of the growing season comparing with clay or sand only. Rice straw covered with sandy soil gave the highest fruit yield, fresh and dry weight and total $N, P, K$ accumulation in vegetative parts and fruits. Total dry matter content and total $\mathrm{N}, \mathrm{P}, \mathrm{K}$ accumulation in vegetative parts were increased with progress of plant age till 120 days from planting and then declined.

AbdAlla-Manal (1995) found that the growing of cucumber on half buried straw bales led to significant increases in number of leaves and plant fresh and dry weights at most stages in two successive years. She also, concluded that early yield was significantly increased by using straw bales half buried in the soil, where fruits number was increased by $255 \%$ and fruits weight by $282 \%$ compared to the soil media (control).

Because of water scarcity problems in arid regions, it has become of primary importance to search for alternative sources of water for agricultural irrigation. Brackish water can be used for irrigation of various crops. In spite of the fact that saline water used for agriculture is associated with some reduction in yield, it can successfully be applied to irrigation, coupled with improved irrigation technology such as subsurface drip irrigation. When brackish water is skillfully used for irrigation, it can contribute to the successful production of crops (Mizrahi and pasternake ,1985).

Abo-soliman et al. (2002) concluded that the irrigation with fresh water achieved the highest fruit yield of tomato, yield per plant, juice percentage and vitamin C. while the yield of tomato is decreased by 11.48 and $25.71 \%$ when irrigated by alternative well water with fresh water and well water respectively.

Salem,(1988) reported that adding organic manure as fertilizer led to decreasing soil $\mathrm{pH}$ which results in increasing nutrients solubility and availability to the plant.

Abo El-Defan (1990) found that addition of chicken manure increased fresh and dry yields of tomato shoots, fruits and the concentration of N,P and $\mathrm{K}$ in both shoots and fruits. 


\section{MATERIALS AND METHODS}

This investigation was conducted in plastic greenhouses at Sakha Agricultural Research Station... The study started in summer growing season 2008 with cucumber seedlings variety Gianco RZ which transplanted on May $, 8^{\text {th }}, 2008$ and harvested on July $, 14^{\text {th }}, 2008$ followed by tomato variety Flora which transplanted on first of November , 2008 and harvested on June $8^{\text {th }}, 2009$. The experiments were carried out in four protected greenhouses with dimension 4-5 $\mathrm{m}$ width and 19- $24 \mathrm{~m}$ length.

Split - split plot design was used and the applied treatments were as follows:

The main treatments (cultivation media):

1 Rice straw bales

2 Ordinary clay soil (in buried cement lysimeters)

Sub - main treatments (different water sources):

1 Fresh water $(0.4 \mathrm{dS} / \mathrm{m})$

2 Well water $(2.9 \mathrm{dS} / \mathrm{m})$.

3 Blended Fresh water with well water $(1.51 \mathrm{dS} / \mathrm{m})$ at ratio of 1:1.

Sub -sub treatments (organic manure levels):

1 Zero level (control).

25 ton / fed.

310 ton / fed.

415 ton / fed.

520 ton / fed.

Soil samples (clayey soil) were taken at $0-15$ and $15-30 \mathrm{~cm}$ depths for chemical analysis. Also, samples were taken from rice straw bales and farmyard manure to determine $\mathrm{N}, \mathrm{P}$ and $\mathrm{K}$, and organic carbon contents as shown in Tables (1 and 2).

Table (1): Soil chemical analysis before planting cucumber in summer season 2008.

\begin{tabular}{|c|c|c|c|c|c|c|c|c|c|c|}
\hline \multirow{3}{*}{$\begin{array}{l}\text { Soil } \\
\text { Depth } \\
\text { (cm) }\end{array}$} & \multirow{3}{*}{$\begin{array}{c}\text { EC } \\
d S / m\end{array}$} & \multirow{2}{*}{\multicolumn{4}{|c|}{ Cations meq /L }} & \multirow{2}{*}{\multicolumn{4}{|c|}{ Anions meq / L }} & \multirow[b]{3}{*}{ SAR } \\
\hline & & & & & & & & & & \\
\hline & & $\mathrm{Na}^{+}$ & $\mathrm{K}^{+}$ & $\mathrm{Ca}^{++}$ & $\mathbf{M g}^{++}$ & $\mathrm{Co}^{-}$ & HСO3- & $\mathrm{Cl}$ & $\mathrm{SO}^{=}=$ & \\
\hline $0-15$ & 2.54 & 17.0 & 0.3 & 4.0 & 5.5 & 0.0 & 4.5 & 11.9 & 10.4 & 7.8 \\
\hline $15-30$ & 2.74 & 18.6 & 0.3 & 4.4 & 6.0 & 0.0 & 5.0 & 13.0 & 11.3 & 8.16 \\
\hline
\end{tabular}

Tale (2): $\mathrm{C} / \mathrm{N}$ ratio for farmyard manure and rice straw bales before planting.

\begin{tabular}{|c|c|c|c|c|c|}
\hline Elements & $\mathbf{N} \%$ & $\mathbf{P} \%$ & $\mathbf{K}(\mathbf{p p m})$ & $\mathbf{C}$ & $\mathbf{C} / \mathbf{N}$ ratio \\
\hline $\begin{array}{c}\text { Farmyard } \\
\text { manure }\end{array}$ & $\mathbf{0 . 6 2}$ & $\mathbf{3 . 9 1}$ & $\mathbf{1 . 4}$ & $\mathbf{3 8 . 2 6}$ & $\mathbf{6 1 . 7 1}$ \\
\hline Rice straw & 0.45 & 2.95 & 1.2 & 29.1 & 67.7 \\
\hline
\end{tabular}




\section{Saied, M. M. et al.}

Preliminary preparations inside greenhouses were implemented before transplanting of cucumber as follows:

1-The plastic sheet was renewed.

2-Rice straw bales were arranged in two rows ( $65 \mathrm{~cm}$.) Width for each plastic house. Each greenhouse contains two rows of buried lysimeters

3-Drip irrigation network was installed on rice straw bales and buried lysimeters ( two laterals per row ) with drippers at $50 \mathrm{~cm}$ spacing The rice straw bales were moisten by irrigation water via drip irrigation system for 10 days ( 4-6 hours a day) to remove soil particles that contaminated rice straw bales .

4-Rice straw bales were twice treated by pigeon manure $(25 \mathrm{~kg}$ pigeon manure soaked in 200 liter tap water for 48 hours and filtered).

5 -The plastic greenhouses were sterilized by silicrone parasitcide at rate of $2 \mathrm{ml} / 1000 \mathrm{ml}$ water .About 50 liter was used for each greenhouse.

6-The recommended doses from the mineral fertilizers in form of ammonium nitrate, super phosphate and potassium sulphate were applied. The agronomic practices were performed as recommended in the area.

\section{Parameters Studied:}

1. Fresh yield of cucumber and tomato were picked two times a week from each plot.

2. Nitrogen content of cucumber and tomato leaves were determined by modified kjeldahl method according to Cottenie et al (1982).

3. Total phosphorus was determined using spectrophotometer method according to Olsen et al. (1965).

4. Total potassium was determined using flame photometer as described by Page (1982)

5. Electrical conductivity (ECe) was measured by electrical conductivity meter as dS/m at $25^{\circ} \mathrm{C}$ in soil paste extract according to Jackson (1967) after harvesting of cucumber and tomato.

The yield and its quality and mineral composition of cucumber and tomato were subjected to the statistical analysis according to Snedecor and Cochran (1967).

\section{RESULTS AND DISCUSSION}

\section{Effect of different treatments on fresh yield:}

\section{A: Cucumber:}

Data in Table (3) reveal that there is a highly significant effect on fresh yield of cucumber. The cultivation of cucumber on rice straw bales lead to increase the fresh yield of cucumber by $23.58 \%$ over than ordinary clay soil The decrease in yield of cucumber which grown in ordinary clay soil may be due to salt accumulation in surface layer. This process might inhibit water and nutrient uptake, and consequently, affects badly on the crop growth and yield.

Concerning the effect of irrigation water sources, data in Table (3) show that the yield of cucumber is reduced significantly by $56.07 \%$ and $25.79 \%$ due to irrigation with well and blended water; respectively as compared to fresh water .This result is agreement with (Mass.1984). According to this trend, cucumber yield reduced by about $75 \%$ when irrigated by water with ECw equals $2.9 \mathrm{dS} / \mathrm{m}$. 
Data also indicated that there is a highly significant effect on cucumber yield due to application of organic manure up to 20 ton/fed. The increase in fruit yield of cucumber is $27.07 \%, 51.13 \% 65.04 \%$ and $87.59 \%$ over the control with $5,10,15$ and 20 ton organic manure /fed, respectively.

\section{B. Tomato:}

Data in Table (3) revealed that, the fresh yield of tomato which cultivated in clay soil is higher by about $10.68 \%$ than that grown on rice straw bales. This result may be due to the deepest roots of tomato in clay soil than that in rice straw bales which increase nutrients uptake from the soil media.

Regarding the irrigation with different water sources, data indicated that the fresh yield of tomato is reduced significantly with irrigation by well and blended water compared to irrigation with fresh water. The decreases are $19.21 \%$ and $8.05 \%$ with well and blended water, respectively.

Concerning organic manure level, data show that there is highly significant effect on tomato fresh yield due to organic manure application levels up to 20 ton/fed. This increase in tomato fresh yield is $3.6 \%, 11.34$, $22.68 \%$ and $32.99 \%$ with 5, 10, 15 and 20 ton/fed organic manure over the control, respectively.

It was observed from data in Table (3) that the interactions between all treatments under study were high significant.

Table (3): Fresh yield of cucumber and tomato as affected by different cultivation media, water sources and organic manure levels

\begin{tabular}{|c|c|c|}
\hline Treatments & Cucumber yield $\left(\mathrm{kg} / \mathrm{m}^{2}\right)$ & Tomato yield $\left(\mathrm{kg} / \mathrm{m}^{2}\right)$ \\
\hline \multicolumn{3}{|c|}{ Cultivation media } \\
\hline \multirow{6}{*}{$\begin{array}{l}\text { Rice straw bales } \\
\text { Clay soil } \\
\text { Mean } \\
\text { F test } \\
\text { LSD } 0.05 \\
\text { LSD } 0.01\end{array}$} & 4.41 & 20.90 \\
\hline & 3.37 & 23.40 \\
\hline & 3.89 & 22.15 \\
\hline & ** & $\star *$ \\
\hline & 0.157 & 0.96 \\
\hline & 0.209 & 1.00 \\
\hline \multicolumn{3}{|l|}{ Water sources } \\
\hline \multirow{7}{*}{$\begin{array}{l}\text { fresh } \\
\text { Well } \\
\text { Blended }(1: 1) \\
\text { Mean } \\
\text { F test } \\
\text { LSD } 0.05 \\
\text { LSD } 0.01\end{array}$} & 5.35 & 24.36 \\
\hline & 2.35 & 19.68 \\
\hline & 3.97 & 22.40 \\
\hline & 3.89 & 22.15 \\
\hline & $\star \star$ & ** \\
\hline & 0.165 & 1.03 \\
\hline & 0.223 & 1.42 \\
\hline \multicolumn{3}{|l|}{ Organic manure levels (ton/fed) } \\
\hline \multirow{8}{*}{$\begin{array}{l}0 \\
5 \\
10 \\
15 \\
20 \\
\text { Mean } \\
\text { F test } \\
\text { LSD } 0.05 \\
\text { LSD } 0.01\end{array}$} & 2.66 & 19.40 \\
\hline & 3.38 & 20.10 \\
\hline & 4.02 & 21.60 \\
\hline & 4.39 & 23.80 \\
\hline & 4.99 & 25.80 \\
\hline & 3.89 & $22_{\star \star}^{2.15}$ \\
\hline & 0.156 & 081 \\
\hline & 0.207 & 1.10 \\
\hline \multicolumn{3}{|l|}{ Interaction } \\
\hline \multirow{4}{*}{$\begin{array}{l}\text { Cultivation } \times \text { water sources } \\
\text { Cultivation } \times \text { organic manure } \\
\text { Water } \times \text { organic } \\
\text { Cultivation } \times \text { water } \times \text { organic }\end{array}$} & $\star \star$ & $\star \star$ \\
\hline & ** & ** \\
\hline & $\star *$ & ** \\
\hline & $\star \star$ & $\star \star$ \\
\hline
\end{tabular}


Effect of different treatments on NPK contents of cucumber and tomato leaves:

A .Cucumber:

Data in Table (4) show that the nitrogen, phosphorus and potassium percentage in leaves of cucumber are affected by cultivation media. The nitrogen and phosphorus are highly significantly increased in leaves of cucumber cultivated in clay soil compared with those grown on rice straw bales. This may be due to the immobilization of $\mathrm{N}$ and in straw bales during the decomposition, whereas, the $\mathrm{N}$ and $\mathrm{P}$ contents in clay soil are $2.01 \%$ and $0.904 \%$, while the content of these elements in rice straw bales are 1.58 and $0.392 \%$, respectively. On contrary to this $\mathrm{K} \%$ is lower in clay soil than rice straw bales, since its content in clay soil is $0.992 \%$ while in rice straw bales is $1.096 \%$.

Data also revealed that the irrigation by different water sources had a highly significant effect on NPK contents in cucumber leaves, whereas these elements are clearly increased when fresh water used in irrigation compared to well and blended water. These results may be attributed to the irrigation by saline water, and consequently decreased NPK concentration in leaves of cucumber, may be inhibit water and nutrient uptake by plant.

Table (4): N, P and $K$ content $\%$ in Cucumber leaves as affected by different cultivation media, water sources and organic manure levels during summer season, 2008.

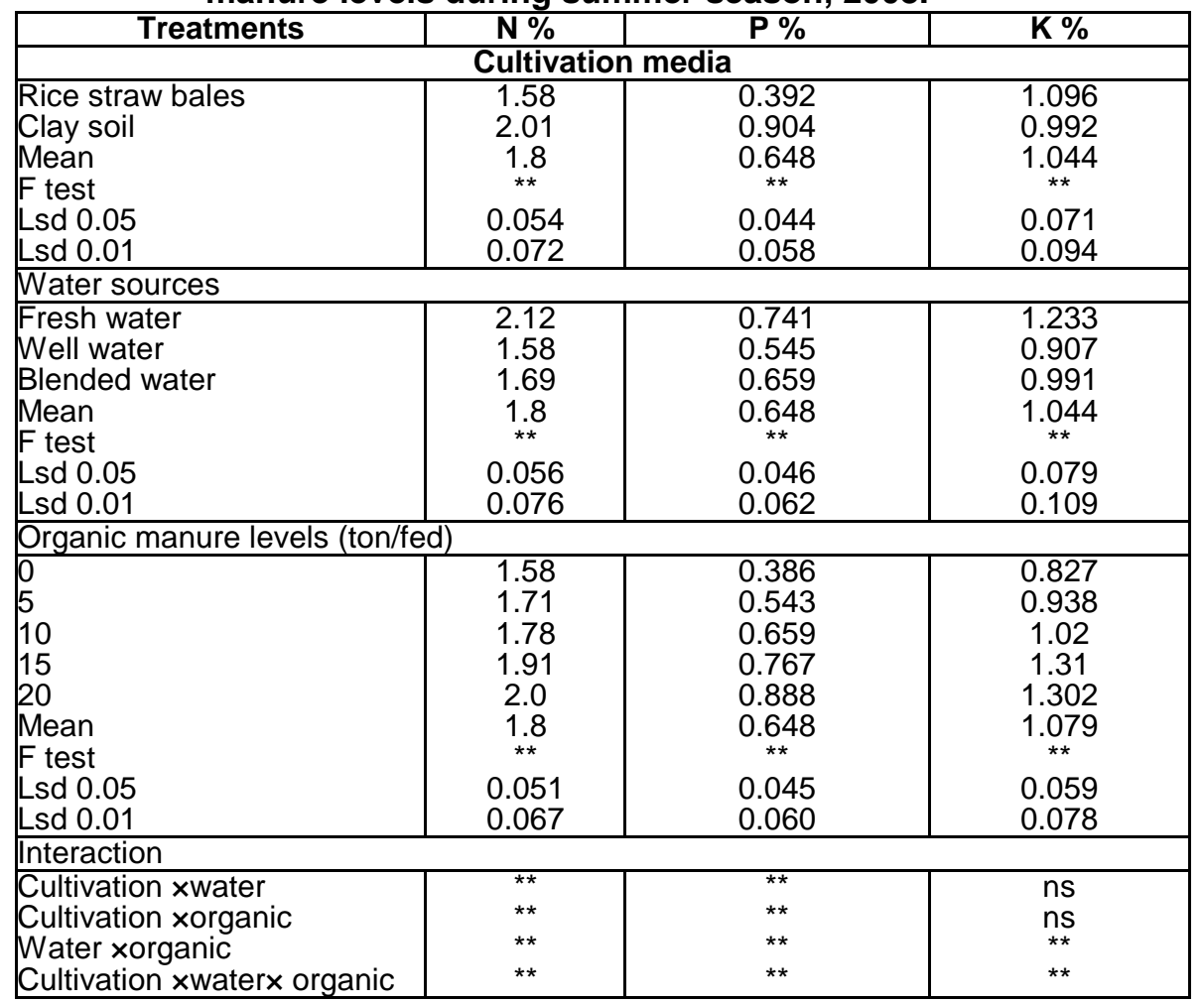


On the other hand, data indicated that, the organic manure levels strongly affect NPK content of leaves of cucumber. Increasing organic manure levels up to 20 ton/fed increase NPK content, from1.58, 0.38 and $0.827 \%$ to $2.0,0.888$ and $1.302 \%$, respectively.

The combination between either cultivation media and water sources or cultivation media and organic manure levels had highly significant effect on nitrogen and phosphorus but not significant with $\mathrm{K}$. While the interaction between water sources, organic manure and cultivation, water, organic had highly significant affect on content NPK of leaves.

\section{B.Tomato:}

Data in Table (5) reveal that, NPK contents of tomato leaves are highly significantly affected by different treatments. Concerning the effect of cultivation media, the $\mathrm{N}$ content in tomato leaves grown in clay soil are higher than those grown on rice straw bales, while the opposite trend is found with $\mathrm{P}$ and $\mathrm{K}$ contents.

Table (5): N, P and $K$ content \% in tomato leaves as affected by different treatments under protected greenhouse in season of 2008/2009.

\begin{tabular}{|c|c|c|c|}
\hline Treatments & $\mathbf{N} \%$ & $\mathbf{P} \%$ & $\mathbf{K} \%$ \\
\hline \multicolumn{4}{|c|}{ Cultivation media } \\
\hline Rice straw bales & 3.048 & 2.67 & 0.162 \\
\hline Clay soil & 4.198 & 1.807 & 0.139 \\
\hline Mean & 3.623 & 2.239 & 0.151 \\
\hline F test & ** & $\star *$ & ** \\
\hline Lsd 0.05 & 0.178 & 0.185 & 0.074 \\
\hline Lsd 0.01 & 0.236 & 0.246 & 0.0098 \\
\hline \multicolumn{4}{|l|}{ Water sources } \\
\hline Fresh water & 4.269 & 2.629 & 0.155 \\
\hline Well water & 3.552 & 2.162 & 0.143 \\
\hline Blended water & 3.084 & 1.926 & .155 \\
\hline Mean & 3.623 & 2.239 & .151 \\
\hline F test & $\star *$ & $\star \star$ & $\star *$ \\
\hline Lsd 0.05 & 0.183 & 0.191 & 0.008 \\
\hline Lsd 0.01 & 0.245 & 0.256 & 0.0096 \\
\hline \multicolumn{4}{|c|}{ Organic manure levels (ton/fed) } \\
\hline 0 & 3.15 & 1.37 & 0.132 \\
\hline 5 & 3.328 & 1.998 & 0.144 \\
\hline 10 & 3.673 & 2.156 & 0.149 \\
\hline 15 & 3.842 & 2.477 & 0.560 \\
\hline 20 & 4.12 & 3.193 & 0.172 \\
\hline Mean & 3.632 & 2.239 & 0.151 \\
\hline F test & $\star \star$ & $\star *$ & $\star \star *$ \\
\hline Lsd 0.05 & 0.186 & 0.194 & 0.007 \\
\hline Lsd 0.01 & 0.247 & 0.258 & 0.009 \\
\hline \multicolumn{4}{|l|}{ Interaction } \\
\hline Cultivation $\times$ water & ** & ** & ** \\
\hline Cultivation $\times$ organic & ** & ** & ** \\
\hline Water $\times$ organic & ** & ** & ** \\
\hline Cultivation $\times$ water $\times$ organic & ** & ** & ** \\
\hline
\end{tabular}


Data also show that NPK contents in tomato leaves are significantly affected by different irrigation water sources . The positive effect of water irrigation sources on NPK contents can be arranged in the following descending order: fresh water $>$ blended water $>$ well water .

Regarding the effect of organic manure, data indicated that increasing organic manure levels from 5 up to 20 ton/fed. Leads to highly significant increase in NPK contents of tomato leaves. These results are agreement with Abu EL-Defan (1990) and Salem (1988). The obtained results indicated also that the interactions between all treatments under study were highly significant as shown in Table (5).

Effect of different treatments on $\mathrm{C} / \mathrm{N}$ ratio of rice straw bales after harvesting of cucumber and tomato:

A. The first season (cucumber):

Data in Table (6) indicated that $\mathrm{C} / \mathrm{N}$ ratio of rice straw bales is decreased after harvesting of cucumber compared to those recorded before the experiment. The highest $\mathrm{C} / \mathrm{N}$ ratio values are obtained with control after harvesting of cucumber (67.7). The obtained results show also that the use of fresh water leads to achieve the lowest values of $\mathrm{C} / \mathrm{N}$ ratio (28.75) comparing to well and blended water (41.60 and $39.72 \%)$, respectively. The increases of application rate of the organic manure led to decrease of $\mathrm{C} / \mathrm{N}$ ratio in rice straw. The increase of application rate of the organic manure up to 20 ton / fed. decreases the $\mathrm{C} / \mathrm{N}$ ratio from 30.7 to 27.1. The lowest $\mathrm{C} / \mathrm{N}$ ratio is obtained from the interaction between fresh water and 20 ton organic manure / fed (17.0). This trend may be attributed to increase the biological activity with fresh water and high rate of organic manure, consequently increase the decomposition of rice straw and clearly decrease $\mathrm{C} / \mathrm{N}$ ratio.

Table (6): $\mathrm{C} / \mathrm{N}$ ratio in rice straw bales as affected by different treatments after harvesting of cucumber(2008)

\begin{tabular}{|c|c|c|c|c|}
\hline $\begin{array}{c}\text { Irrigation water } \\
\text { sources }\end{array}$ & $\begin{array}{l}\text { Organic manure } \\
\text { levels(ton/fed) }\end{array}$ & $\mathrm{C} \%$ & $\mathrm{~N} \%$ & $\mathrm{C} / \mathrm{N}$ ratio \\
\hline \multirow{6}{*}{ Fresh water } & Control & 29.1 & 0.43 & 67.70 \\
\hline & 5 & 19.81 & 0.96 & 20.64 \\
\hline & 10 & 25.20 & 1.45 & 17.38 \\
\hline & 15 & 23.79 & 1.12 & 21.05 \\
\hline & 20 & 26.01 & 1.53 & 17.00 \\
\hline & Mean & & & 28.75 \\
\hline \multirow{6}{*}{ Well water } & Control & 29.1 & 0.43 & 67.70 \\
\hline & 5 & 23.62 & 0.60 & 39.37 \\
\hline & 10 & 22.99 & 0.66 & 34.76 \\
\hline & 15 & 21.03 & 0.63 & 33.38 \\
\hline & 20 & 20.97 & 0.64 & 32.77 \\
\hline & Mean & & & 41.60 \\
\hline \multirow{6}{*}{$\begin{array}{l}\text { Blended water (1:1 } \\
\text { fresh: wall) }\end{array}$} & Control & 29.1 & 0.43 & 67.70 \\
\hline & 5 & 21.73 & 0.68 & 31.96 \\
\hline & 10 & 24.06 & 0.70 & 34.37 \\
\hline & 15 & 22.15 & 0.67 & 33.06 \\
\hline & 20 & 21.74 & 0.69 & 51.50 \\
\hline & Mean & & & 39.72 \\
\hline
\end{tabular}




\section{B - The second season (tomato):}

The data in Table (7) show that $\mathrm{C} / \mathrm{N}$ ratio values at the end of the 2 nd season are lower than those after harvesting of cucumber (the 1st season). The deceasing of the $\mathrm{C} / \mathrm{N}$ ratio to be lower than 20 indicates that the rice straw is completely decomposed and ready to be safely used for soil improvement. It is clear that $\mathrm{C} / \mathrm{N}$ ratio with different treatments is lower than the control. Also, the $\mathrm{C} / \mathrm{N}$ ratio with blended water is lower than that with fresh and well water (12.70, 18.34 and 26.82 respectively).

Concerning the effect of organic manure, the results reveal that the lowest value of $\mathrm{C} / \mathrm{N}$ ratio (13.36) is achieved with 20 ton organic manure and blended water. While, the highest value (30.32) is recorded with 5 ton organic manure /fed and well water.

The decreasing of $\mathrm{C} / \mathrm{N}$ ratios were happened at the highest rate of added organic manure due to increasing the rate of organic matter decomposition specially with fresh water or blended water. Whereas, well water tend to decrease the rate of decomposition .

Table (7): $\mathrm{C} / \mathrm{N}$ ratio in rice straw bales as affected by different treatments after Harvesting of tomato $(2008$ / 2009).

\begin{tabular}{|c|c|c|c|c|}
\hline $\begin{array}{l}\text { Irrigation water } \\
\text { sources }\end{array}$ & $\begin{array}{c}\text { Organic manure } \\
\text { levels(ton/fed) }\end{array}$ & $\mathbf{C} \%$ & $\mathrm{~N} \%$ & $\mathrm{C} / \mathrm{N}$ ratio \\
\hline \multirow{6}{*}{ Fresh water } & Control & 28.28 & 0.93 & 30.41 \\
\hline & 5 & 18.81 & 1.07 & 17.58 \\
\hline & 10 & 22.20 & 1.42 & 15.63 \\
\hline & 15 & 20.70 & 1.47 & 14.10 \\
\hline & 20 & 22.80 & 1.63 & 14.00 \\
\hline & Mean & & & 18.34 \\
\hline \multirow{6}{*}{ Well water } & Control & 28.28 & 0.94 & 30.41 \\
\hline & 5 & 20.62 & 0.68 & 30.32 \\
\hline & 10 & 19.90 & 0.77 & 25.84 \\
\hline & 15 & 18.30 & 0.74 & 24.73 \\
\hline & 20 & 17.80 & 0.78 & 22.82 \\
\hline & Mean & & & 26.82 \\
\hline \multirow{6}{*}{$\begin{array}{l}\text { Blended water (1:1 } \\
\text { fresh: wall) }\end{array}$} & Control & 28.28 & 0.94 & 30.41 \\
\hline & 5 & 15.25 & 0.85 & 17.94 \\
\hline & 10 & 11.45 & 0.75 & 15.27 \\
\hline & 15 & 11.12 & 0.80 & 13.90 \\
\hline & 20 & 10.70 & 0.80 & 13.38 \\
\hline & Mean & & & 12.70 \\
\hline
\end{tabular}

\section{Conclusion:}

Using rice straw bales as cultivation media resulted in increasing cucumber yield and decreasing tomato yield compared to clay soil. The fresh yield for both cucumber and tomato decreased with increasing irrigation water salinity , as well as, the rate of organic matter decomposition. 


\section{REFFRENCES}

Abd-Alla. Manal. A. (1995): Studies on cucumber production in alternatives of ordinary soils .MSc. Thesis, Kafr El-Sheikh, Tanta Univ.

Abo.El-Defan, T.R.(1990). Effect of organic manure on plant growth and nutrient uptake under saline condition. M.Sc.Thesis, Fac. of Agric, Ain shams Univ,Cairo,Egypt.

Abo-soliman, M.S.M; M .M. Saied; S. M .El-Barbary and M.M. Ragab (2002).Saline water management for tomato production under greenhouses at North Nile Delta, Egypt. $2^{\text {nd }}$ inter.Conf.Hort.Sci. 1012sept.2002.Kafr El-sheikh. Tanta Univ. Egypt.

Abou - El - Hassan, E.A; Khereba A.H. , Youssef , M.S. , Zaki , M.H. and .H Khalifa (1993) studies on using some local media for two successive years without sterilization on plant growth, yield and natural uptake of cucumber grown under unheated greenhouses in Egypt. Symposium on soil and soilless media under protected cultivation in mild winter climates,. ( Cairo Univ., Dept of Hortculture, Giza , Egypt.

Cottenie, A.; Verso, M.; Kiekens, L.; Veighe, G. and R. Camerlynck (1982) .Chemical Analysis of Plants and Soils . Lab .Anal .and Agrochem. State Univ., Gent .Belgium, Chapter 2, 3, PP.14-54

ELAidy. F. L.(1993). Preliminary results on the possibility of using straw as natural substrata for growing cucumber under plastic greenhouse. Symposium on Soil and Soilless Media under protected cultivation in mild winter climates. Publication 1 February 1993, Tanta Univ.,Cairo, Egypt.

Jackson, M.L.(1967):Soil Chemical Analysis. Hall of Prentice India Ltd. New Delhi.

Mass, E.V.(1984): Salt tolerance of plants, In: Handbook of Plant Science in Agriculture,. B.R. Christie Ed, Florida, U.S.A

Mizrahi, Y. and D. pasternake (1985). Effect of salinity on quality of various agricultural crops. Plant and soil 89:301-307.

Olsen, S .R. Colc and F.S. Watanabe (1954).Test of an ascorbic acid method for determining phosphorus in water and $\mathrm{NaHCO} 3$ extracts from soil. Soil Sci.Amr.Proc.29:677-678.

Page, A, L. (1982). Methods of Soil Analysis .Part 2: Chemical and Microbiological Properties ( $2^{\text {nd }}$ ed) Amer. Soc .Agron .In Soil Sci .Soc .Amer.Inc .Madison, Wisconsin, USA, Chapter 12, PP.199-223.,

Salem, N.(1987):Evaluation of some parameters influencing the use of conditioners in soils, Inter. Symp. on Soil Conditioners, Desert Research Center, Cairo, Egypt., Pp.81-91

Snedecor, G.W and W.G. Cochran (1967). "Statistical Method". 6 th ed. Oxford and IB4.Publishing Co, Calcutta, India. 
تأثير بيئسات النمـو, مصـادر ميـاه الري ومستويات السـماد العضوي على محصول

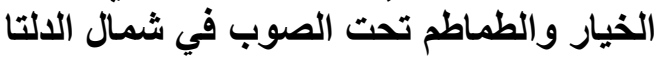

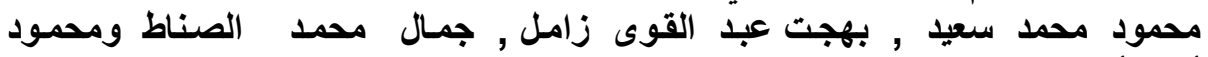

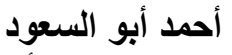
معهد بحوث الأراضي والمياه والبيئة ـ- مركز البحوث الزراعية

أجريت تجربة في صوب بلاستيكية بمحطة البحوث الزر اعية بسخا في الموسم الصيفي

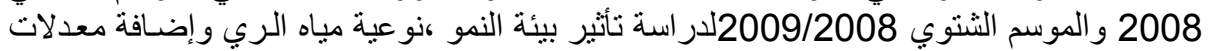

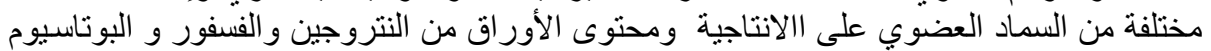

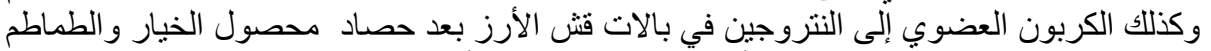

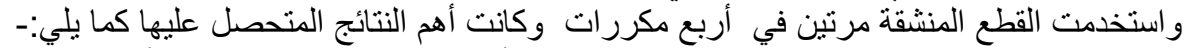

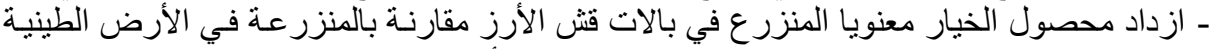

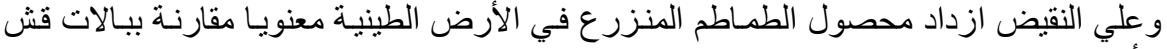

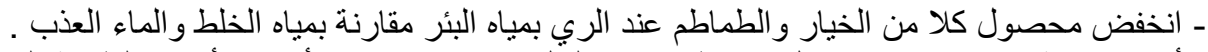

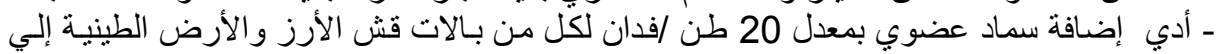

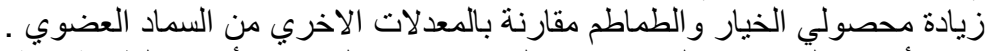

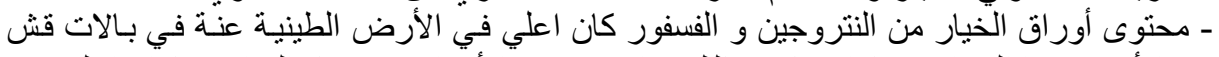

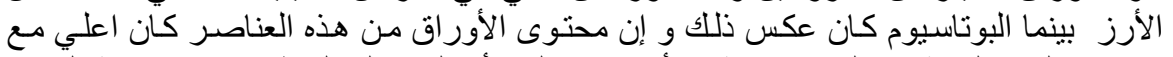

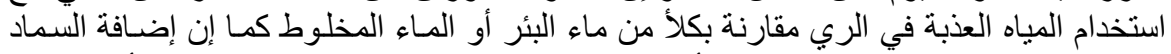

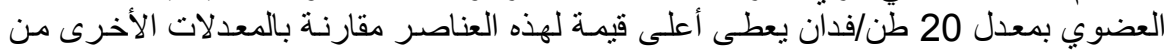

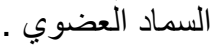

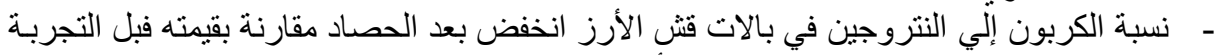

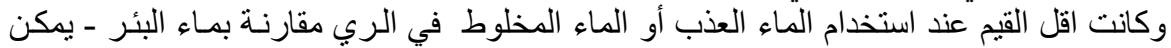

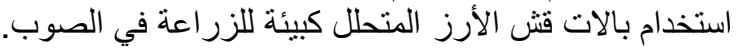

كلية الزراعة - جامعة المنصورة مركز البحوث الزراعية
قام بتحكيم البحث

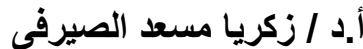

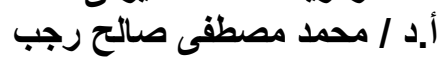

